\title{
Intraocular lens explantation or exchange: indications, postoperative interventions, and outcomes
}

\author{
Remoção ou troca de lentes intraoculares: indicações, intervenções pós-operatórias e resultados

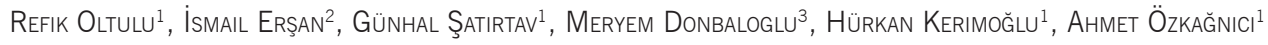

\begin{abstract}
Purpose: To analyze the indications for explantation or exchange of intraocular lenses (IOLs), which were originally implanted for the correction of aphakia during cataract extraction.

Methods: All cases that involved intraocular lens explantation or exchange in one institution between January 2008 and December 2014 were analyzed retrospectively.

Results: In total, 93 eyes of 93 patients were analyzed. The median time interval between implantation and explantation of the anterior chamber intraocular lenses (AC IOL) and posterior chamber intraocular lenses (PC IOL) was $83.40 \pm 83.14$ months (range: 1-276 months) and $55.14 \pm 39.25$ months (range: 1-168 months), respectively. Pseudophakic bullous keratopathy (17 eyes, 38.6\%) and persistent iritis (12 eyes, $27.8 \%$ ) in the AC IOL group and dislocation or decentration (30 eyes, 61.2\%) and incorrect IOL power (nine eyes, 18.4\%) in the PC IOL group were the most common indications for explantation of $\mathrm{OOLs}$. The mean logMAR best corrected visual acuity (BCVA) improved significantly from 1.30 preoperatively to 0.62 postoperatively in the $P C I O L$ group $(p<0.001)$ but did not improve significantly in the AC IOL group ( $p=0.186)$.

Conclusions: The primary indication for $1 \mathrm{OL}$ explantation or exchange was pseudophakic bullous keratopathy in the AC IOL group and was dislocation or decentration in the PC IOL group. PC IOL explantation or exchange is safe and improves visual acuity.

Keywords: Cataract extraction; Lenses, intraocular; Reoperation; Device removal; Lens implantation, intraocular; Pseudophakia; Corneal diseases; Patient satisfaction; Visual acuity
\end{abstract}

\section{RESUMO}

Objetivo: Analisar as indicações para a remoção ou troca de lentes intraoculares (IOL), que foram originalmente implantadas para a correção de afacia após a extração da catarata.

Método: Todos os casos que envolveram remoção ou troca de lentes intraoculares em uma única instituição, entre janeiro de 2008 e dezembro 2014 foram analisados retrospectivamente.

Resultados: No total, foram analisados 93 olhos de 93 pacientes. Ointervalo de tempo médio entre o implante e a remoção das LIOs de câmara anterior (ACIOL) e de câmara posterior (PCIOL) foi 83,40 $\pm 83,14$ meses (variando de 1 a 276 meses) e 55,14 $\pm 39,25$ meses (variando de 1 a 168 meses), respectivamente. Ceratopatia bolhosa pseudofácica (17 olhos, 38,6\%) e irite persistente (12 olhos, 27,8\%) no grupo AC IOL, e deslocamento ou descentralização (30 olhos, 61,2\%) e poder incorreto da IOL (nove olhos, 18,4\%), no grupo PC IOL, foram as indicações mais comuns para a remoção das $10 \mathrm{Ls}$. A média logMAR da melhor acuidade visual corrigida (BCVA) melhorou significativamente a partir de 1,30 no pré-operatório para 0,62 no pós-operatório no grupo $P C I O L(p<0,001)$, mas não melhorou significativamente no grupo AC IOL $(p=0,186)$.

Conclusões: A principal indicação para remoção ou troca de lentes intraoculares foia ceratopatia bolhosa pesudofácica no grupo ACIOL e deslocamento ou descentralização no grupo PCIOL. A remoção ou troca de PC IOLs é segura e melhora a acuidade visual.

Descritores: Extração de catarata; Lentes intraoculares; Reoperação; Remoção de dispositivo; Implante de lente intraocular; Pseudofacia; Doenças da córnea; Satisfação do paciente; Acuidade visual

\section{INTRODUCTION}

Cataracts are one of the most common eye diseases associated with blindness (visual acuity worse than 20/400 in the better eye with best correction) worldwide, with an estimated 18 million people thought to be affected, and cataract surgery is the intraocular procedure performed most often worldwide. Over the years, the techniques of cataract surgery have evolved into a safe and successful procedure for visual rehabilitation. The incidence of most complications has significantly decreased with the development of better instrumentation and affordable, high-quality intraocular lens (IOL) implants (1). Various aspects of cataract surgery that make it safer have changed considerably in the past decade with the evolution of both surgical techniques and IOL designs.

Although cataract surgery is safe for the majority of patients, some complications that involve the anterior and posterior segment can occur. Surgical procedures involving the use of the modern anterior chamber (AC) IOLs (AC IOLs) and posterior chamber (PC) IOLs (PC IOLs) have reduced the risk of complications necessitating IOL explantation/exchange. Although older types of both AC IOLs and PC IOLs are no longer implanted since the advent of the new generation IOLs, we still see complications associated with those implanted many years ago. The aim of this study was to analyze the indications and outco-
Submitted for publication: December 17, 2014

Accepted for publication: March 6, 2015

Department of Ophthalmology, School of Medicine, Necmettin Erbakan University, Konya, Turkey. Department of Ophthalmology, School of Medicine, Canakkale Onsekiz Mart University, Canakkale, Turkey.

${ }^{3}$ Department of Ophthalmology, Mus State Hospital, Mus, Turkey.
Funding: No specific financial support was available for this study.

Disclosure of potential conflicts of interest: None of the authors have any potential conflicts of interest to disclose.

Corresponding author: Ismail Ersan. Department of Ophthalmology - School of Medicine. Canakkale Onsekiz Mart Universitesi Tip Fakultesi. Goz Hastalıkları AD - Canakkale - Turkey E-mail: isersan@gmail.com

Approved by the following research ethics committee: Necmettin Erbakan University School of Medicine. 
mes of $A C$ and $P C I O L$ explantation conducted at a single institution between 2008 and 2014.

\section{METHODS}

This retrospective interventional case series study has been conducted in accordance with the tenets of the Declaration of Helsinki and with the approval of the Ethics Committee of Necmettin Erbakan University School of Medicine. The medical records for 93 eyes of 93 patients who had an AC or PC IOL explantation/exchange performed at Necmettin Erbakan University School of Medicine from 2008 to 2014 were reviewed for data including gender, age, the mean interval between cataract surgery and IOL explantation, the presence of pseudoexfoliation (PEX), glaucoma, corneal edema, uveitis, the presence of myopia or hyperopia, and best corrected visual acuity (BCVA) before and after the explantation/exchange. The exclusion criteria were a follow-up period shorter than 1 month and patients with incomplete medical records. Otherwise, all the patients with IOL explantation/ exchange were included. Descriptive statistics were calculated for various clinical characteristics, and all data were analyzed using SPSS for Windows (version 16.0, SPSS Inc., Chicago, IL, USA).

\section{RESULTS}

Ninety-three patients with AC and PC IOL explantation/exchange were recruited. Forty-four patients had $A C I O L$ s and 49 patients had $P C$ IOLs. The patients were evaluated in two groups accordingly. Table 1 shows the characteristics of patients in each group. The median time intervals between implantation and explantation of the AC IOL and PC IOL groups were $83.40 \pm 83.14$ months (range: 1-76 months) and $55.14 \pm 39.25$ months (range: 1-168 months), respectively.

\section{AC IOL GROUP}

The mean preoperative intraocular pressure in the $\mathrm{AC} \mathrm{IOL} \mathrm{group}$ was $18.05 \pm 8.49 \mathrm{mmHg}$ (range: 6-44). Four patients used timolol + dor-

Table 1. Characteristics of patients with AC and PC IOL explantation

\begin{tabular}{lcc}
\hline Characteristics & AC IOL group & PC IOL group \\
\hline Sex, $\mathrm{n}(\%)$ & $19(43 \%)$ & $37(75.5 \%)$ \\
$\quad$ Male & $25(57 \%)$ & $12(24.5 \%)$ \\
Female & & \\
Age $(\mathrm{y})$ & $65.9 \pm 17.0$ & $52.84 \pm 24.60$ \\
Mean \pm SD & $20-83$ years & $3-86$ years \\
Range & & \\
Interval between surgeries & $83.14 \pm 83.40$ & $55.14 \pm 39.25$ \\
Mean \pm SD & $1-276$ months & $1-168$ months \\
Range &
\end{tabular}

$\mathrm{AC} I \mathrm{OL}=$ anterior chamber intraocular lens; $\mathrm{PC} \mathrm{IOL}=$ posterior chamber intraocular lens, $\mathrm{SD}=$ standard deviation zolamide (Cosopt, MSD, Turkey), while two patients used timolol + dorzolamide (Cosopt, MSD, Turkey) and brimonidine tartrate (Alphagan P, Abdi Ibrahim, Turkey).

The most common reasons for explantation of the AC IOLs were pseudophakic bullous keratopathy (PBK) (17 eyes, 38.6\%) and persistent iritis (12 eyes, 27.8\%) (Table 2). After AC IOL explantation, a scleral fixated PC IOL was placed in 12 eyes (27.3\%), and a PC IOL was implanted in six eyes (13.6\%) above the remnant of the capsule at the sulcus without suturing. Finally, 26 (59.1\%) eyes were left aphakic (Table 3). The mean logMAR BCVA had improved from 2.00 preoperatively to 1.80 postoperatively, but the difference did not reach statistical significance $(p=0.186)$. The BCVA improved in 21 eyes $(47.7 \%)$, remained stable in 17 eyes (38.6\%), and decreased in six eyes (13.6\%). The BCVA improved in patients with PBK and persistent iritis in two eyes (11.8\%) and eight eyes (66.7\%), respectively. The mean intraocular pressure of all the subjects was within the normal range, with 15 (34.1\%) patients requiring topical anti-glaucomatous medication. Intraoperative and postoperative complications are shown in table 5.

\section{PC IOL GROUP}

The mean preoperative intraocular pressure was $16.69 \pm 7.42 \mathrm{mmHg}$ (range: 7-40). Three patients used timolol + dorzolamide (Cosopt, MSD, Turkey), while two patients used timolol + dorzolamide (Cosopt, MSD, Turkey) and brimonidine tartrate (Alphagan P, Abdi Ibrahim, Turkey).

The most common indications for explantation of the PC IOLs were dislocation/decentration (30 eyes, 61.2\%) and postoperative residual refractive error due to incorrect IOL power calculation (nine eyes, 18.4\%). Other indications were IOL opacification (six eyes, 12.2\%), persistent iritis (three eyes, 6.1\%), and uveitis glaucoma hyphema (UGH) syndrome (one eye, 2\%) (Table 4). After the PC IOL explantation, a new PC IOL could be implanted into the capsular bag in 15 eyes (30.6\%) and above the remnant of the capsule without suturing in 13 eyes (26.5\%). If the capsular remnant did not offer adequate support for a PC IOL, a scleral fixated IOL was placed (17 eyes, 34.7\%). Finally, four eyes (8.2\%) were left aphakic (Table 3). The mean logMAR BCVA had improved significantly from 1.30 preoperatively to 0.62 postoperatively $(p<0.001)$. The BCVA improved in 37 eyes $(75.5 \%)$, remained stable in four eyes (8.2\%), and decreased in eight eyes (16.3\%). Although 12 patients required topical anti-glaucomatous medications, the mean intraocular pressure of all the subjects was within the normal range. Intraoperative and postoperative complications are shown in table 5.

\section{DISCUSSION}

Cataract extraction ranks among the most commonly performed surgical procedures in the United States ${ }^{(2)}$. As a consequence of the large number of operations performed worldwide, increased use of IOLs leads to an increase in the number of complications requiring explantation of the IOLs, despite the marked improvement in surgical procedures and IOL technologies.

Table 2. Indications for AC IOL explantation and relation to age and intervals between surgeries

\begin{tabular}{|c|c|c|c|}
\hline Indications & Eyes n (\%) & Age, year (mean \pm SD) & Interval between surgeries, month (mean \pm SD) \\
\hline Pseudophakic bullous keratopathy & $17(38.6)$ & $68.88 \pm 15.84$ & $121.06 \pm 87.73$ \\
\hline Persistent iritis & $12(27.8)$ & $67.50 \pm 13.57$ & $41.75 \pm 34.71$ \\
\hline IOL decentration & $6(13.6)$ & $66.00 \pm 18.06$ & $64.50 \pm 90.23$ \\
\hline Glaucoma & $5(11.4)$ & $61.20 \pm 18.21$ & $121.40 \pm 82.84$ \\
\hline UGH & $2(4.5)$ & $78.50 \pm 4.95$ & $1.00 \pm 0.00$ \\
\hline Refractive error & $1(2.3)$ & 20.00 & 180.00 \\
\hline Glare & $1(2.3)$ & 39.00 & 2.00 \\
\hline
\end{tabular}

$\mathrm{ACIOL}=$ anterior chamber intraocular lens; $\mathrm{UGH}=$ uveitis glaucoma hyphema syndrome. 
Table 3. IOL fixation technique used after IOL explantation

\begin{tabular}{lcc}
\hline Fixation technique & AC-IOL group & PC-IOL group \\
\hline PC IOL in bag & $0(0 \%)$ & $15(30.6 \%)$ \\
PC IOL in sulcus & $6(13.6 \%)$ & $13(26.5 \%)$ \\
PC IOL with scleral fixation & $12(27.3 \%)$ & $17(34.7 \%)$ \\
Aphakia & $26(59.1 \%)$ & $4(8.2 \%)$ \\
\hline
\end{tabular}

$\mathrm{AC} \mathrm{IOL=} \mathrm{anterior} \mathrm{chamber} \mathrm{intraocular} \mathrm{lens;} \mathrm{PC} \mathrm{IOL=} \mathrm{posterior} \mathrm{chamber} \mathrm{intraocular} \mathrm{lens.}$

Table 4. Indications for PC IOL explantation and relation to age and intervals between surgeries

\begin{tabular}{lccc}
\hline Indications & Eyes n (\%) & $\begin{array}{c}\text { Age, year } \\
\text { (mean } \mathbf{\pm} \text { SD) }\end{array}$ & $\begin{array}{c}\text { Interval between surgeries, } \\
\text { month (mean } \pm \text { SD) }\end{array}$ \\
\hline $\begin{array}{l}\text { IOL dislocation/ } \\
\text { decentration }\end{array}$ & $30(61.2)$ & $58.60 \pm 22.89$ & $65.06 \pm 41.21$ \\
Incorrect IOL power & $9(18.4)$ & $31.44 \pm 28.34$ & $48.00 \pm 32.86$ \\
IOL opacification & $6(12.2)$ & $59.00 \pm 8.79$ & $40.00 \pm 22.34$ \\
Persistent iritis & $3(6.1)$ & $45.67 \pm 27.75$ & $32.67 \pm 35.80$ \\
UGH & $1(2.0)$ & 57.00 & 2.00 \\
\hline
\end{tabular}

$\mathrm{PCIOL}=$ posterior chamber intraocular lens; $\mathrm{UGH}=$ uveitis glaucoma hyphema syndrome.

Table 5. Intraoperative and postoperative complications of intraocular lens explantation

\begin{tabular}{|c|c|c|}
\hline & AC IOL group & PC IOL group \\
\hline \multicolumn{3}{|l|}{ Intraoperative complications } \\
\hline Vitreous loss & $8(18.2 \%)$ & $6(12.2 \%)$ \\
\hline Bleeding to the anterior chamber & $4(9.1 \%)$ & $3(6.1 \%)$ \\
\hline Suprachoroidal hemorrhage & $2(4.5 \%)$ & - \\
\hline \multicolumn{3}{|l|}{ Postoperative complications } \\
\hline Bullous keratopathy & $2(4.5 \%)$ & - \\
\hline Cystoid macular edema & $1(2.3 \%)$ & - \\
\hline Corneal melting requiring evisceration & $1(2.3 \%)$ & - \\
\hline Endophthalmitis & - & $1(2.0 \%)$ \\
\hline
\end{tabular}

$\mathrm{AC} \mathrm{IOL=}$ anterior chamber intraocular lens; $\mathrm{PC} \mathrm{IOL}=$ posterior chamber intraocular lens.

In a series of 102 patients who had IOL explantation or exchange, AC IOLs comprised $66.7 \%$ of the removed lenses. PBK, followed by UGH syndrome and cystoid macular edema were the most frequent indications for explantation or exchange ${ }^{(3)}$. Similarly, PBK and UGH were the most common indications for AC IOL explantation (53.9\%), followed by iris-fixated lenses $(33.7 \%)^{(4)}$. Marques et al. reported that their rate of PBK was only $6.7 \%$, while the main indication was inflammation (UGH and persistent iritis) with a rate of $53.3 \%{ }^{(5)}$. In this study, PBK (17 eyes, 38.6\%) was the most common indication, in accordance with Mamalis et al. ${ }^{(3)}$ and Doren et al. ${ }^{(4)}$, for AC IOL explantation, which had a rate of $47.3 \%$. Preventing the need for penetrating keratoplasty, AC IOL explantation has been indispensable in eyes with signs of progressive corneal endothelial damage ${ }^{(6)}$. In our series, intervals between surgeries in patients with PBK and persistent iritis were $126.7 \pm 89.7$ months (range: $6-276$ months) and $41.4 \pm 38.6$ months (range: 2-120 months), respectively. Early explantation of the AC IOLs may prevent progressive endothelial cell loss, as observed in the fact that BCVA improved in only two eyes (11.8\%) in patients with PBK who had a longer time interval between surgeries and improved in eight eyes (66.7\%) in patients with persistent iritis who had a shorter time interval between surgeries ${ }^{(7,8)}$.

In the latest survey update in 2007 of members of the American Society of Cataract and Refractive Surgeons and the European Socie- ty of Cataract and Refractive Surgeons, Mamalis et al. reported that dislocation/decentration, incorrect IOL power calculation, glare/optical aberrations, and IOL calcification were the most common reasons for PC IOL explantation ${ }^{(9)}$. Furthermore, Jones et al. investigated indications of IOL exchange and found that IOL dislocation (46\%) was the most common indication and that PC IOLs accounted for $88.5 \%$ of all decentered IOL ${ }^{(10)}$.

$\mathrm{OOL}$ dislocation is a rare complication in which the patient complains of blurred vision, glare, and possibly diplopia. The visual symptoms can be potentially disabling to the patient, and the condition requires intervention in either repositioning or even removing the lens. Patients with PEX are at risk for IOL dislocation after uncomplicated cataract surgery. Although IOLs can be well secured in the capsular bag, the possibility of progressive loss of zonular integrity may cause late endocapsular subluxation of PC IOLs. In our series, nine patients with PEX had IOL extraction because of delayed dislocation; the mean interval between implantation and exchange was 78 months. The current study at a single institution demonstrated that PC IOL dislocation (61.2\%) was the most common indication for extracting PC IOLs, followed by incorrect IOL power (18.4\%). This was similar to the findings reported by Mamalis et al. ${ }^{(9)}$ and Jones et al. ${ }^{(10)}$. According to the time interval between cataract surgery and IOL dislocation, IOL dislocation can be classified as early dislocation if it occurs within 3 months and late dislocation if it occurs after more than 3 months. Improper fixation within the capsular bag and instability of the capsular bag-IOL complex are the major causes of $\mathrm{IOL}$ dislocation ${ }^{(10)}$. The major causes of early IOL dislocation are improper support of the capsular bag and ciliary sulcus due to zonular or capsular damage, rupture, or both ${ }^{(11)}$. Late dislocations are often accompanied by trauma or progressive zonular dehiscence caused by contraction of the capsular bag many years after routine cataract surgery ${ }^{(12)}$. In the present study, early IOL dislocation was present in six eyes after complicated cataract surgery with vitreous loss, in one eye after ocular trauma, and in one eye with a broken IOL haptic. Of the 22 eyes with late IOL dislocation, the major predisposing factors were PEX in nine eyes (40.9\%), trauma in seven eyes (31.8\%), and capsule contracture syndrome in three eyes (13.6\%). No predisposing factor could be found in the remainder (three eyes, 13.6\%).

Unpredicted postoperative refractive error due to preoperative incorrect IOL power calculation is a disturbing complication for cataract surgeons. Improved IOL calculation formulas and preoperative measurement of axial length and corneal curvature reduce the risk of this complication. In our study, nine (18.4\%) eyes required IOL explantation due to incorrect IOL power. The IOLs were exchanged because of postoperative myopia in five eyes and hyperopia in four eyes. Our results were in accordance with a recent study in which IOL dislocation (46\%) followed by incorrect IOL power (23\%) were the most common causes of IOL exchange ${ }^{(10)}$.

IOL opacification is a rare but possible event. The exact reason for opacification is unknown. Using microscopic analyses of explanted hydrophilic acrylic IOLs, Werner et al. revealed multiple fine, calcified granular deposits of variable sizes within the lens optics ${ }^{(13)}$. Neuhann et al. concluded that it was important to determine whether the calcium deposits formed because of a problem in IOL manufacturing (properties of the polymer, its surface, or the IOL packaging) or were the result of environmental causes that can catalyze calcification ${ }^{(14)}$. In the present study, five of the six patients with IOL opacifications had a history of diabetes mellitus, which may have contributed to IOL opacifications by catalyzing calcification.

By using a proper IOL stabilizing technique, intraocular tissues should be protected from damage that could be caused by IOLs, and appropriate refractive outcomes should therefore be achieved. Secondary scleral fixated IOL implantation after IOL removal was the dominant procedure used to avoid further corneal complications in both the AC IOL and PC IOL groups in our study. 
Postoperative corneal decompensation after IOL explantation was heavily dependent on the initial measurement of endothelial cell density ${ }^{(15,16)}$. It is important to bear in mind that IOL explantation has a risk of additional damage to corneal endothelial cells. Coli et al. showed progression of corneal decompensation in $23.5 \%$ of eyes after $\mathrm{ACIOL}$ explantation ${ }^{(17)}$. In the current study, only two eyes (4.5\%) developed postoperative PBK in the AC IOL explantation group, and postoperative PBK was not observed in the $P C I O L$ explantation group. The low incidence of progression to PBK in the AC IOL explantation group, compared with Coli et al. ${ }^{(17)}$ may be attributed to the higher proportion of patients that were left aphakic in our study. With the application of proper techniques, BCVA improved in 21 eyes (47.7\%) in the AC IOL group and in 37 eyes (75.5\%) in the PC IOL group.

This study had several shortcomings, including its retrospective nature and a lack of information on the IOL types that were explanted, lack of measurements of preoperative and postoperative endothelial cell density, and the highly variable follow-up times. Although the mean follow-up time was $7.2 \pm 9.6$ months and some of the cases had 48 months of follow-up, some cases had 1 month of follow-up, which was insufficient to detect some of the postsurgical complications.

In conclusion, the main indications for IOL explantation/exchange in the AC IOL and PC IOL groups were PBK and IOL dislocation/ decentration, respectively. PC IOL explantations/exchanges have more favorable outcomes with an increase in BCVA than AC IOL explantations/exchanges, in which inflammation and corneal complications were much more common.

\section{REFERENCES}

1. Pascolini D, Mariotti SP. Global estimates of visual impairment: 2010. Br J Ophthalmol. 2012;96(5):614-8.
2. American Academy of Ophthalmology Preferred Practice Pattern: Cataract in the Adult Eye. 2011. Available at: http://one.aao.org/asset.axd?id=8d66318f-ff50-408e-9bb173d277cf14ce.

3. Mamalis N, Crandall AS, Pulsipher MW, Follett S, Monson MC. Intraocular lens explantation and exchange. A review of lens styles, clinical indications, clinical results, and visual outcome. J Cataract Refract Surg. 1991;17(6):811-8.

4. Doren GS, Stern GA, Driebe WT. Indications for and results of intraocular lens explantation. J Cataract Refract Surg. 1992:18(1):79-85.

5. Marques FF, Marques DM V, Osher RH, Freitas LL. Longitudinal study of intraocular lens exchange. J Cataract Refract Surg. 2007;33(2):254-7.

6. Liarakos VS, Ham L, Dapena I, Tong CM, Quilendrino R, Yeh RY, et al. Endothelial keratoplasty for bullous keratopathy in eyes with an anterior chamber intraocular lens. J Cataract Refract Surg. 2013;39(12):1835-45.

7. Rao GN, Stevens RE, Harris JK, Aquavella JV. Long-term changes in corneal endothelium following intraocular lens implantation. Ophthalmology. 1981;88(5):386-97.

8. Morrison LK, Waltman SR. Management of pseudophakic bullous keratopathy. Ophthalmic Surg. 1989:20(3):205-10.

9. Mamalis N, Brubaker J, Davis D, Espandar L, Werner L. Complications of foldable intraocular lenses requiring explantation or secondary intervention-2007 survey update. J Cataract Refract Surg. 2008:34(9):1584-91.

10. Jones JJ, Jones YJ, Jin GJC. Indications and outcomes of intraocular lens exchange during a recent 5-year period. Am J Ophthalmol. 2014;157(1):154-62.

11. Mönestam El. Incidence of dislocation of intraocular lenses and pseudophakodonesis 10 years after cataract surgery. Ophthalmology. 2009;116(12):2315-20.

12. Jehan FS, Mamalis N, Crandall AS. Spontaneous late dislocation of intraocular lens within the capsular bag in pseudoexfoliation patients. Ophthalmology. 2001;108(10): 1727-31

13. Werner L, Apple DJ, Kaskaloglu M, Pandey SK. Dense opacification of the optical component of a hydrophilic acrylic intraocular lens: a clinicopathological analysis of 9 explanted lenses. J Cataract Refract Surg. 2001;27(9):1485-92

14. Neuhann IM, Kleinmann G, Apple DJ. A new classification of calcification of intraocular lenses. Ophthalmology. 2008;115(1):73-9.

15. Panton RW, Viana MG, Panton PJ, Panton JH. Long-term follow-up of leiske closed-loop anterior chamber intraocular lenses. J Cataract Refract Surg. 2000;26(4):590-6.

16. Lee DA, Price FW. Management of concurrent corneal diseases and cataract. Curr Opin Ophthalmol. 1993;4(1):97-101.

17. Coli AF, Price FW, Whitson WE. Intraocular lens exchange for anterior chamber intraocular lens-induced corneal endothelial damage. Ophthalmology. 1993;100(3):384-93.

\title{
VIII Congresso Nacional da \\ VIII Congresso Nacional da Sociedade Brasileira de Oftalmologia
}

\author{
9 a 11 de julho de 2015 \\ Centro Internacional de Convenções do Brasil
}

Brasília - DF

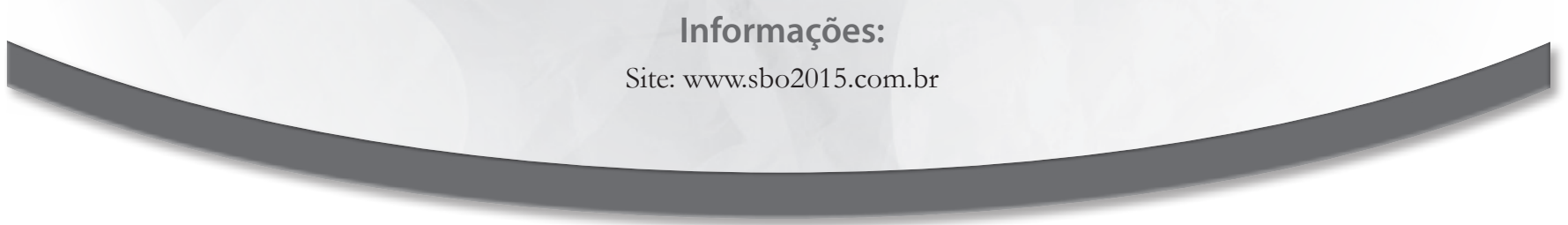

